\title{
ANALISIS KEBIJAKAN STABILISASI HARGA MINYAK GORENG INDONESIA
}

\author{
Oleh \\ Ketut Sunarta \\ Dosen Fakultas Ekonomi Universitas Pakuan
}

\begin{abstract}
ABSTRAK
Tujuan penelitian ini adalah untuk menjelaskan gejolak harga minyak goreng di dalam negeri dan mempelajari upaya pemerintah dalam menstabilkan harga minyak goreng. Komoditas ini merupakan komoditas penting - karena termasuk sembilan bahan pangan pokok dan menyangkut kesejahteraan rakyat banyak.

Kebijakan stabilisasi harga minyak goreng domestik dilakukan baik kebijakan pada sisi input maupun kebijakan pada sisi output. Dari sisi input, intervensi kebijakan dilakukan melalui kebijakan Domestic Market Obligation (DMO) dan pengenaan Pajak Ekspor Progresif (Progressive Tax Export). Hampir 70\% industri minyak goreng sawit di Indonesia memiliki karakteristik pola pengusahaan yang terintegrasi secara vertikal. Sehingga kebijakan yang menghambat pemasaran produk pada bagian hulu (output berupa CPO) akan dialihkan sebagai beban (bahan baku/input) pada proses produksi berikutnya sehingga akan mempengaruhi kenaikan harga produk pada lini hilir (output berupa minyak goreng).

Secara kumulatif potensi penurunan margin keuntungan yang ditimbulkan akibat dari implementasi kebijakan pemerintah pada lini produksi hulu dapat dikompensasikan dengan sempurna oleh pelaku usaha melalui kenaikan harga produk yang dihasilkan lini produksi hilir.

Intervensi kebijakan dari sisi output Minyak Goreng sawit dilakukan melalui kebijakan PPN DTP dan program Minyakita, dan hasil studi menemukan bahwa kebijakan ini relatif tidak berpengaruh terhadap penurunan harga minyak goreng di dalam negeri.
\end{abstract}

Kata kunci : Stabilisasi harga, Domestic Market Obligation, Pajak Ekspor 


\section{PENDAHULUAN}

\subsection{Latar Belakang}

Fenomena beberapa tahun terakhir menunjukkan adanya gejolak harga CPO dunia, dan berdampak pada gejolak harga minyak goreng di pasar domestik. Meningkatnya harga CPO dari kisaran harga US\$ 600/ton pada bulan Februari 2007 menjadi US\$ 1.300/ton pada minggu pertama Maret 2008 mengakibatkan kenaikan harga minyak goreng sawit di pasar domestik dari Rp 7.000/kg (Februari 2007) menjadi Rp 12.900 per kg (Maret 2008). Hal ini antara lain disebabkan oleh karena $80 \%$ biaya produksi pengolahan minyak goreng sawit merupakan biaya bahan baku CPO.

Stabilisasi harga kebutuhan pokok termasuk minyak goreng merupakan salah satu program kebijakan pemerintah, yang dilakukan untuk menjaga standar kelayakan hidup masyarakat. Produk minyak goreng menjadi salah satu barang yang penting untuk dikendalikan karena menyangkut kepentingan masyarakat banyak. Rata-rata konsumsi minyak goreng per kapita di Indonesia mencapai 10,4 kg per tahun (BPS, 2007).

Namun, ketika terjadi penurunan harga di pasar input (CPO), harga minyak goreng di pasar domestik tidak berespon secara proporsional. Hal ini dapat memicu terjadinya perilaku ataupun praktek persaingan usaha tidak sehat yang dilakukan oleh para pelaku usaha minyak goreng di Indonesia (sehingga mengkondisikan harga minyak goreng relatif tetap tinggi meskipun variabel input (CPO) telah mengalami penurunan harga yang signifikan).

Industri minyak goreng tidak terlepas dari industri hulu, yakni industri CPO domestik. Selain untuk memenuhi kebutuhan domestik, komoditas CPO juga memiliki orientasi ekspor yang sangat tinggi. Hal ini disebabkan oleh permintaan CPO dunia yang setiap tahun meningkat dengan laju 1,96\% per tahun.

Kelebihan permintaan CPO di pasar dunia mencerminkan laju permintaan lebih besar dibandingkan dengan laju peningkatan produksi, sehingga harga CPO dunia terus meningkat. Peningkatan harga tersebut berdampak pada fluktuasi ekspor CPO Indonesia dan sekaligus dapat mengakibatkan kenaikan harga minyak goreng domestik. Oleh sebab itu, untuk melindungi konsumen dalam negeri, studi tentang stabilisasi harga ini menarik untuk dilakukan.

\subsection{Identifikasi Permasalahan}

Secara umum permasalahan yang akan difokuskan dalam studi ini adalah:

1. Bagaimanakah struktur pasar minyak goreng di pasar domestik? 
2. Bagaimanakah gambaran struktur, perilaku dan kinerja pasar minyak goreng di pasar domestik?

3. Bagaimanakah dampak persaingan dari kebijakan pemerintah dalam upaya melakukan stabilisasi harga minyak goreng di pasar domestik?

\subsection{Tujuan Penelitian}

Sesuai dengan identifikasi masalah di atas, tujuan studi ini adalah sebagai berikut:

1. Untuk mengetahui struktur pasar minyak goreng di pasar domestik;

2. Untuk mengidentifikasi perilaku produksi dan pemasaran minyak goreng serta menganalisis kinerja pasar minyak goreng di pasar domestik;

3. Untuk mengidentifikasi kebijakan stabilisasi harga minyak goreng yang dilakukan oleh pemerintah .

\section{TINJAUAN PUSTAKA}

Harga ditentukan oleh interaksi kekuatan permintaan dan kekuatan penawaran. Oleh sebab itu, kerangka teori dalam penelitian ini untuk stabilisasi harga - khususnya untuk menueunkan harga - adalah upayaupaya yang sistematis untuk menggeser kurva penawaran ke kanan, sebagaimana dijelaskan pada gambar berikut.

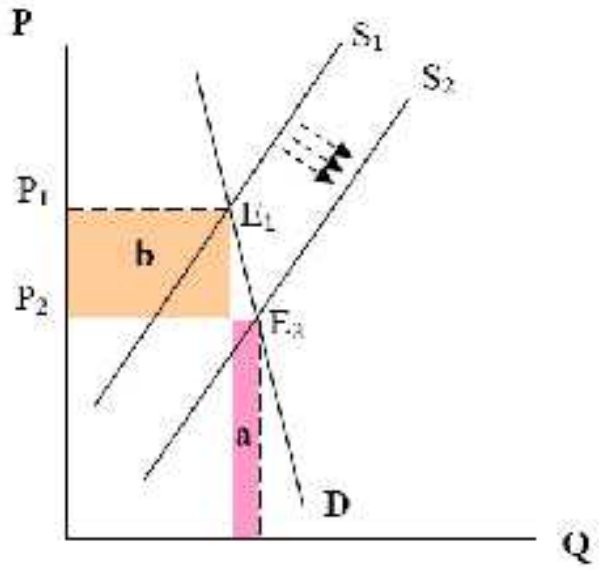

Gambar 1. Kerangka Teori Stabilisasi Harga

Karakteristik permintaan minyak goreng bersifat inelastik dapat digambarkan dengan kurva D yang relatif curam. Pengaruh pajak akan 
mengakibatkan kurva supply mengalami pergeseran. Kurva S1 menggambarkan kondisi penawaran ketika pemerintah menerapkan pajak sebesar T. Dalam hal penghapusan pajak sebesar T, kurva supply akan bergeser ke kanan yaitu dari S1 ke S2, sehingga harga (penjualan minyak goreng) pun akan bergerak dari P1 ke P2. Namun dengan memahami karakteristik permintaan minyak goreng yang inelastik, pengaruh penghapusan pajak relatif tidak akan mendorong pergerakan harga ke titik P2. Hal ini dapat terjadi karena implikasi penurunan pajak hanya memberikan potensi tambahan revenue sebesar luasan 'a' dengan kehilangan potensi revenue sebesar luasan 'b'. Secara logis pelaku usaha hanya akan mempertukarkan dua alternatif yang minimal sama-sama menguntungkan. Oleh sebab itu, ketika pemerintah berkebijakan untuk menghapuskan pajak (misalnya dengan Progran PPn-DTP pada minyak goreng curah) maka harga produk tersebut akan turun minimal sebesar nilai pajak yang dikenakan. Dengan terjadinya penurunan harga maka secara teoritis jumlah output yang dimintapun akan bertambah. Namun seiring dengan potensi bertambahnya jumlah output yang diminta, pelaku usaha tidak serta merta akan menambah produksinya untuk kemudian dijual ke pasar. Mereka akan meningkatkan produksinya jika dan hanya jika nilai tambahan revenue yang akan mereka peroleh lebih besar daripada nilai tambahan revenue sebelumnya (ketika masih dikenakan pajak).

\section{INDUSTRI DAN PERDAGANGAN MINYAK GORENG SAWIT}

Minyak Goreng Sawit (MGS) merupakan salah satu komoditas strategis karena termasuk salah satu dari 9 bahan kebutuhan pokok bangsa Indonesia. Permintaan MGS di dalam dan di luar negeri yang kuat merupakan indikasi pentingnya peranan komoditas kelapa sawit dalam perekonomian bangsa. Kebutuhan MGS terus meningkat dari tahun ke tahun seiring bertambahnya jumlah penduduk, berkembangnya pabrik dan industri makanan, dan meningkatnya konsumsi masyarakat akan minyak goreng untuk memasak.

Keunggulan kompetitif Indonesia sendiri dibandingkan dengan negara lain yaitu sumber daya alamnya, sedangkan keunggulan komparatif Indonesia dalam agribisnis yaitu sebagai negara tropis yang mendapat dinar matahari yang melimpah sepanjang tahun dengan curah hujan yang cukup dan hampir merata. Kondisi inilah yang sangat 
dibutuhkan oleh tanaman kelapa sawit sebagai bahan baku MGS.

Indonesia adalah negara produsen utama minyak sawit dunia. Pangsa produksi minyak sawit Indonesia saat ini kurang lebih sebesar 36 persen dari total produksi dunia, sedangkan Malaysia telah mencapai kontribusi sebesar 47 persen. Sehingga secara bersama-sama, Indonesia dan Malaysia praktis menguasai 83 persen produksi dunia. Peluang Indonesia untuk menggenjot produksi masih sangat besar, terutama dengan ketersediaan lahan, kesesuaian iklim, ketersediaan tenaga kerja relatif murah yang melimpah, serta biaya pembangunan dan perawatan per hektar yang juga lebih murah.

Produk utama adalah minyak sawit, CPO dan PKO, yang selanjutnya menjadi bahan baku industri hilir pangan maupun non pangan. Di samping produk utama CPO dan PKO serta produk-produk turunannya secara lebih rinci dalam pohon industri kelapa sawit dan potensi produk-produk sampingan seperti tandan kosong, pelepah dan batang, serta limbah padat dan limbah cair.

Pabrik minyak goreng di Indonesia telah berkembang di 13 propinsi. Wilayah terluas terdapat di Sumatera, diikuti Jawa, Sulawesi dan Kalimantan. Lima propinsi terluas berturut-turut adalah Sumatera Utara (30.46\%), Riau (24.83\%), DKI Jakarta (13.01\%), Jawa Timur (9.62\%) dan Sumatera Selatan (7.18\%).

Dalam satu dekade terakhir, industri kelapa sawit Indonesia berkembang cukup pesat. Sistem agroindustri kelapa sawit di Indonesia semakin lama semakin berkembang karena dipengaruhi oleh kondisi industri yang saling kompetitif. Dalam perkembangannya sistem agroindustri kelapa sawit mengalami berbagai macam perubahan strategi yang menuntut untuk menjaga kelangsungan efisiensi dan efektivitas operasional sistem agroindustri kelapa sawit. Salah satu strategi untuk menciptakan suatu efisiensi dan efektivitas di dalam agroindustri kelapa sawit di Indonesia adalah dengan menerapkan sistem integrasi vertikal sehingga semua sistem dan subsitem yang ada di agroindustri kelapa sawit dapat berjalan terintegrasi dan saling terkait sehingga akan menimbulkan suatu unit usaha atau unit kerja yang berjalan secara efisien.

Dalam pola pemilikan dan pengusahaan kelapa sawit di Indonesia terdapat perusahaan minyak goreng yang terintegrasi dengan perkebunan CPO dan ada pula perusahaan minyak goreng yang tidak terintergrasi dengan perkebunan CPO. Di Indonesia, Karakteristik 
industri minyak goreng adalah sebanyak 32\% non integrasi, sisanya sebanyak $66 \%$ terintegrasi.

\section{KEBIJAKAN STABILISASI HARGA MINYAK GORENG}

Beberapa kebijakan stabilisasi harga minyak goreng yang telah diambil pemerintah diantaranya melalui pengendalian sisi hulu (input) berupa kebijakan Domestic Market Obligation (DMO) untuk komoditi CPO serta kebijakan Pajak Ekspor (PE) Progressive. Pada sisi hilirnya (output) pemerintah menerbitkan kebijakan stabilisasi harga minyak goreng secara langsung melalui operasi pasar (OP) minyak goreng bersubsidi dan pembebasan PPN untuk penjualan minyak goreng curah (PPN-DTP). Di samping kebijakan-kebijakan tersebut, yang terbaru pemerintah menerbitkan kebijakan yang dikenal dengan Program Minyakita pada awal tahun 2009.

\subsection{Intervensi Kebijakan Pemerintah pada Sisi Input}

\section{a. Domestic Market Obligation}

Domestic Market Obligation (DMO) merupakan kebijakan pemerintah untuk menstabilkan harga minyak goreng secara tidak langsung dengan mewajibkan produsen CPO memasok kebutuhan bahan baku industri minyak goreng. Pada mulanya DMO hanya didasarkan melalui komitmen ataupun kesepakatan diantara para produsen CPO yang kemudian dituangkan dalam bentuk kebijakan pemerintah melalui SK Menteri Pertanian No. 339/Kpts/PD.300/5/2007.

Pasokan CPO yang wajib dipenuhi oleh produsen CPO untuk bulan Mei 2007 sebesar 97.525 ton dan bulan Juni sebesar 102.800 ton. Pasokan minyak goreng tersebut dikirim ke pabrik minyak goreng di Medan, Jakarta, Semarang dan Surabaya. Harga CPO yang dipasok tersebut menurun secara bertahap sampai harga akhir Rp. 5.700 per kg (termasuk PPN 10\%) sampai di lokasi pabrik minyak goreng yang telah ditentukan. Gabungan Pengusaha Kelapa Sawit Indonesia (GAPKI) bertugas mengkoordinasikan, mengawasi jumlah dan jadwal penyerahan CPO dari perusahaan perkebunan ke pabrik minyak goreng.

Dalam pelaksanaannya komitmen-komitmen perusahaanperusahaan dalam memenuhi alokasi pasokan yang ditetapkan dalam DMO tidak terealisasi sepenuhnya. Bulan Mei 2007 hanya terealisasi 59\% (dari komitmen DMO CPO berjumlah 97.525 ton), sedangkan sampai dengan 12 Juni hanya terealisasi 10\% (dari komitmen Juni dan carry over bulan Mei 142.781 ton). Sampai waktu tersebut DMO tidak berlanjut. 


\section{b. Pajak Ekspor Progresif}

Sejak tanggal 3 September 2007, formulasi pengenaan Pajak Ekspor (PE) mengalami perubahan dari yang sebelumnya single rate menjadi progresif mengikuti perkembangan harga internasional. Tarif PE CPO dan produk lainnya sesuai Peraturan Menteri Keuangan adalah sebagai berikut: Jika harga CPO di pasar internasional di bawah US\$ 550 per ton, tarif PE sebesar 0\%. Jika harga CPO US\$ 550- 649 per ton, tarif PE 2,5\%. Harga CPO mencapai US\$ 650-749 per ton, maka PE ditetapkan 5\% dan jika harga CPO mencapai US\$ 750-849 per ton, diberlakukan PE 7,5\%. Kemudian jika harga melampaui US\$ 850, PE sebesar 10\%. PE untuk produk turunan CPO seperti minyak goreng curah (crude olein), refined bleached deodorized (RBD) olein (minyak goreng kemasan), RBD PKO serta stearin, kernel stearin, olein, dan RBD palm oil ditetapkan $0 \%$ pada harga US\$ 550 per ton, 1,5\% pada harga US\$ 550- 649 per ton, $4 \%$ pada harga US\$ 650-749 per ton, dan 6,5\% pada harga US\$ 750-849 per ton. Kemudian mulai harga US\$ 850 per ton ditetapkan PE 9\%. Sementara untuk TBS dan IS dikenai $40 \%$.

\subsection{Intervensi Kebijakan Pemerintah Pada Sisi Output}

\section{a. Pajak Pertambahan Nilai Ditanggung Pemerintah}

Melalui Keputusan Menteri Keuangan nomor 188/011/2007 tanggal 24 September 2007, Pemerintah memberikan fasilitas pembebasan PPN (atau PPN ditanggung pemerintah selanjutnya disebut PPN-DTP) untuk jenis minyak goreng curah dan tidak bermerek ditingkat produsen terhitung mulai tanggal 25 September 2007. Dalam pelaksanaannya, setiap faktur Pajak Keluaran produsen dan penjual minyak goreng di-cap "DTP". PPN sendiri merupakan pajak yang dikenakan atas setiap pertambahan nilai dari barang dan atau jasa dalam peredarannya dari produsen ke konsumen. Indonesia menganut sistem tarif tunggal PPN yaitu sebesar $10 \%$.

Dengan demikian secara definitif dapat dikemukakan bahwa PPNDTP adalah pajak terutang suatu perusahaan, baik swasta maupun BUMN yang ditanggung pemerintah melalui penyediaan pagu anggaran dalam subsidi pajak. Kebijakan tersebut diadopsi pemerintah dalam rangka mendorong investasi dan melakukan stabilisasi harga pada saat perekonomian global melambat dan harga komoditas meningkat.

Melalui mekanisme ini, PPN 10\% (termasuk komponen harga minyak goreng dari produsen ke distributor) akan disubsidi dalam bentuk Di-Tanggung-Pemerintah (DTP) memanfaatkan dana "Subsidi Minyak Goreng" yang sudah dialokasikan. Berdasarkan data APBN-P 
2007 Pemerintah menentukan subsidi untuk PPN-DTP sebesar Rp 325 milyar. Sedangkan untuk tahun anggaran 2008 DPR telah menyetujui anggaran subsidi khusus minyak goreng senilai Rp 600 miliar atau Rp 275 miliar lebih tinggi dibandingkan anggaran serupa di 2007.

Pada tahun angggaran 2009 pemerintah melalui Peraturan Menteri Keuangan menerbitkan Permenkeu No.231/PMK.011/2008 yang mengatur mengenai Pajak Pertambahan Nilai Ditanggung Pemerintah Atas Penyerahan Minyak Goreng Sawit Dalam Negeri Untuk Tahun Anggaran 2009. Dalam Peraturan tersebut disebutkan bahwa pemerintah telah mengalokasikan anggaran sebesar Rp 800 miliar untuk memberikan fasilitas Pajak Pertambahan Nilai Ditanggung Pemerintah (PPN DTP) minyak goreng sawit.12 Fasilitas PPn-DTP diberikan kepada produsen minyak goreng sawit yang memproduksi :

1. minyak goreng curah, dan/atau

2. minyak goreng kemasan sederhana yang dijual dengan merek Minyakita

Fasilitas PPn-DTP untuk minyak goreng kemasan sederhana hanya diberikan kepada perusahaan yang mengikuti ketentuan sebagaimana diatur dalam Pasal 1 ayat (2) Peraturan Menteri Keuangan No 231/PMK.011/2008, Diatur dalam Pasal 2 ayat (1) Peraturan Menteri Keuangan No 231/PMK.011/2008 yang ditetapkan oleh Departemen Perdagangan melalui Peraturan Menteri Perdagangan No. 02/MDAG/PER/1/200914

\section{c. Kebijakan Minyakita}

Kebijakan Minyakita (selanjutnya disebut Program Minyakita) diatur melalui dua kebijakan teknis, yaitu Peraturan Menteri Keuangan No. 231/PMK.011/2008 tentang Pajak Pertambahan Nilai Ditanggung Pemerintah Atas Penyerahan Minyak Goreng Sawit Dalam Negeri Untuk Tahun Anggaran 2009 dan Peraturan Menteri Perdagangan No. 02/MDAG/PER/1/2009 tentang Minyak Goreng Kemasan Sederhana.

Program Minyakita merupakan program kerjasama antara pemerintah dengan produsen minyak goreng nasional untuk menyediakan produk minyak goreng kemasan sederhana yang higienis dan terjangkau bagi masyarakat. Latar belakang pemerintah melaksanakan program Minyakita adalah masih banyaknya perdagangan minyak goreng yang dilakukan dalam keadaan curah15, dimana kondisi sanitasi, higienitas, dan keamanannya masih sangat rendah. Selain itu, jika dilihat dari sisi harga, fluktuasi harga minyak goreng curah di pasar domestik dianggap tidak menguntungkan konsumen dalam negeri, khususnya pada saat harga minyak goreng tinggi seperti saat ini. Atas 
dasar tersebut pemerintah menetapkan kebijakan program Minyakita untuk mencapai dua tujuan utama, yaitu meningkatkan keamanan pangan serta menjaga stabilisasi harga minyak goreng di pasar domestik.

Dalam Pasal 1 ayat (1) Permendag No 02/M-DAG/PER/1/2009 disebutkkan bahwa Minyakita merupakan merek untuk minyak goreng sawit berkualitas curah yang dikemas menggunakan kemasan plastik sederhana dalam bentuk bantal (pillow pack) ukuran 1 liter. Merek Minyakita adalah merek yang dimiliki oleh Pemerintah (Departemen Perdagangan cq Ditjen Perdagangan Dalam Negeri) dan dapat digunakan secara sukarela oleh seluruh produsen minyak goreng.

Untuk dapat memproduksi dan memasarkan minyak goreng dengan merek Minyakita, perusahaan minyak goreng perlu mengikuti prosedur yang terdapat dalam Peraturan Menteri Keuangan No 231/PMK.011/2008 dan Permendag No 02/M-DAG/PER/1/2009 sebagai berikut :

1. Setiap produsen minyak goreng sawit yang akan menggunakan merek Minyakita wajib mendaftarkan diri terlebih dahulu di Departemen Perdagangan cq Ditjen Perdagangan Dalam Negeri.17 Bagi produsen yang tergabung dalam asosiasi (GIMNI dan AIMMI) akan dikoordinir oleh masing-masing asoisasi, sedangkan bagi produsen yang belum tergabung dalam asosiasi dapat mendaftar langsung kepada Departemen Perdagangan.

2. Sebelum menyalurkan Minyakita ke konsumen, produsen wajib mendapatkan ijin edar berupa nomor MD dari Badan POM.

3. Untuk mendapatkan ijin edar dari Badan POM, Departemen Perdagangan akan memberikan rekomendasi kepada produsen. Kemudian Badan POM akan memproses permohonan ijin edar tersebut dengan perlakuan khusus (target waktu).

Dalam Pasal 2 ayat (1) Permendag No 02/M-DAG/PER/1/2009 disebutkan bahwa produsen dapat menjual Minyakita melalui dua mekanisme, yaitu 1) penjualan langsung melalui program KSP, atau 2) penjualan secara komersial melalui distributor/pengecer.

Penjualan langsung melalui program KSP Penjualan langsung melalui program Kepedulian Sosial Perusahaan (KSP) merupakan penjualan Minyakita langsung ke pemukimanpemukiman masyarakat dengan harga jual pabrik. Program KSP Minyakita ini identik dengan program operasi pasar minyak goreng bersubsidi yang pernah dilakukan pemerintah pada tahun 2007 - 2008, yang membedakan adalah penjualannya dilakukan di pemukiman masyarakat dan "subsidi" yang diberikan bukan berasal dari pemerintah melainkan dari produsen 
minyak goreng. Oleh sebab itulah program ini dinamakan program kepedulian sosial perusahaan (KSP/CSR).

Target pemerintah untuk penjualan Minyakita melalui program KSP adalah 1.000 ton per bulan, sesuai kesanggupan dari masing-masing produsen. Sampai dengan saat ini, dari 24 perusahaan minyak goreng yang sudah terdaftar di Departemen Perdagangan, 10 perusahaan minyak goreng sudah aktif mengikuti program KSP Minyakita.

\section{ANALISIS STRUKTUR PASAR}

Secara umum permasalahan yang akan difokuskan dalam pengkajian sektor industri minyak goreng sawit kali ini adalah mengenai gambaran struktur, perilaku dan kinerja pasar minyak goreng di pasar domestik. Hal tersebut dapat dilakukan dengan menggunakan metode pemdekatan S-C-P atau Structure Conduct Performance.

Prinsip dasar S-C-P adalah bahwa kinerja ekonomi industri adalah fungsi perilaku pembeli dan penjual yang merupakan fungsi struktur industri (Mason, 1939; Bain, 1956). Perilaku pasar diukur dari syaratsyarat untuk memaksimalisasi kesejahteraan. Kinerja pasar merujuk pada aktivitas pembeli dan penjual dalam industri yang bersangkutan. Aktivitas penjual termasuk instalasi dan penggunaan kapasitas, kebijakan promosi dan penetapan harga, penelitian dan perkembangan, dan strategi persaingan atau kerjasama antar perusahaan. Struktur industri (penentu kinerja) dilihat dari variabel tersebut yaitu jumlah dan ukuran pembeli dan penjual, teknologi, tingkat perbedaan produk, banyak sedikitnya integrasi vertikal, dan entry barrier (Scherer, 1980:4).

Struktur pasar industri minyak goreng adalah oligopolistik, dengan jumlah pelaku usaha yang relatif banyak dengan karakteristik industri dimana hampir 68\%nya memiliki karakteristik pengusahaan yang mengintegrasikan usaha hulu (perkebunan) dan usaha hilir (pengolahan). Berikut disajikan data 10 pelaku usaha terbesar beserta kapasitas produksi dan market share masing-masing perusahaan minyak goreng di Indonesia

\section{KESIMPULAN DAN REKOMENDASI}

\subsection{Kesimpulan}

1. Struktur pasar industri minyak goreng di Indonesia memiliki karakteristik oligopoli longgar (loose oligopoly) yang dapat ditunjukan dengan mencermati nilai CR4 $(42.60 \%)$ dan nilai HHI $(662,4)$. Nilai 
tersebut masih di bawah dari karakteristik pasar dengan struktur oligopoli ketat (tight oligopoly) yang dipatok pada nilai HHI di atas 1800 dan konsentrasi di atas $60 \%$.

2. Meskipun struktur pasar memiliki karakteristik oligopoli longgar mendekati persaingan) namun dengan mencermati data pergerakan harga minyak goreng di tingkat konsumen periode Januari 2006 Maret 2009, mengindikasikan bahwa harga perdagangan minyak goreng di pasar domestik lebih ditentukan oleh kemampuan perusahaanperusahaan minyak goreng. Hal ini tercermin dari dua perilaku sebagai berikut :

a. Pada saat terjadi kenaikan harga CPO di pasar dunia, perusahaan minyak goreng di Indonesia diduga melakukan consious parallelism, dengan cara menggunakan informasi pasar pergerakan harga input (CPO) internasional dalam menetapkan harga jual minyak goreng di pasar domestik.

b. Pada saat terjadi penurunan harga $\mathrm{CPO}$ di pasar dunia, diduga terjadi asymetric price transmission, yang terlihat dari semakin melebarnya selisih antara harga CPO dengan harga minyak goreng.

3. Terkait dengan kinerja industri minyak goreng sawit di Indonesia menunjukan fakta masih rendahnya utilisasi kapasitas produksi ratarata masih sebesar $53.97 \%$. Hal ini berpengaruh terhadap tingginya harga jual produk per satuan unitnya. Kondisi ini jauh berbeda dengan kinerja pasar (input CPO dan olein) di Malaysia. Selisih antara input CPO dengan output minyak goreng di Malaysia jauh lebih rendah dibandingkan dengan di Indonesia.

4. Terkait dengan kebijakan stabilisasi harga minyak goreng, intervensi kebijakan dari sisi input CPO melalui kebijakan DMO dan PE Progresif belum mampu mendorong terjadinya penurunan harga minyak goreng di pasar domestik. Hal ini diduga disebabkan oleh karena hampir 70\% industri minyak goreng sawit di Indonesia memiliki karakteristik pola pengusahaan yang terintegrasi secara vertikal. Sehingga kebijakan yang menghambat pemasaran produk pada lini hulu (output berupa CPO) akan dialihkan sebagai beban (bahan baku/input) pada proses produksi berikutnya sehingga akan mempengaruhi kenaikan harga produk pada lini hilir (output berupa minyak goreng). Dengan kata lain, secara kumulatif potensi penurunan margin keuntungan yang ditimbulkan akibat dari implementasi kebijakan pemerintah pada lini produksi hulu dapat dikompensasikan dengan sempurna oleh pelaku usaha melalui kenaikan harga produk yang dihasilkan lini produksi hilir; 
5. Selain itu, intervensi kebijakan dari sisi output MGS melalui kebijakan PPN DTP dan program Minyakita pun relatif tidak berpengaruh terhadap penurunan harga minyak goreng di dalam negeri. Hal ini diduga disebabkan oleh :

1. Implementasi PPN-DTP tidak mengakibatkan bertambahnya output di pasar karena bukan merupakan variabel yang dapat mempengaruhi penurunan biaya produksi perusahaan;

2. Implementasi kebijakan Minyakita relatif belum menurunkan harga minyak goreng (terutama kemasan) di pasar domestik dikarenakan substansi kebijakan tersebut praktis hanya akan dimanfaatkan para pelaku usaha dalam industri bersangkutan dalam mendeferensiasi produknya di pasar.

\subsection{Saran}

1. Guna lebih mendorong peningkatan efisiensi industri minyak goreng sawit, pemerintah perlu memfasilitasi kebijakan yang mendorong pelaku usaha untuk meningkatkan utilisasi kapasitas pabrik terpasangnya secara progresif sekaligus meningkatkan daya saing produk turunan CPO di pasar dunia;

2. Pemerintah perlu memfasilitasi regulasi guna memperbaiki kelembagaan pasar (domestik), sehingga meminimalisir perilaku conscious parallelisme (dengan selalu mengacu pada harga pasar internasional) dari para produsen input CPO untuk pengolahan MGS. Hal ini memungkinkan untuk dapat dilakukan mengingat Indonesia merupakan produsen utama dan terbesar CPO dunia. Oleh sebab itu, peran bursa berjangka komoditi perlu diefektifkan;

3. Terkait inefisiensi yang terjadi di industri minyak goreng sawit dalam negeri khususnya jika dikaitkan dengan karakteristik industri yang sebagian besar melakukan pola pengelolaan yang terintegrasi secara vertikal, maka direkomendasikan agar KPPU tetap melakukan penelitian di sektor ini secara berkelanjutan.

\section{DAFTAR PUSTAKA}

Bailey, D dan Brorsen, BW. (1989), Price Asymmetry in Spatial Fed Cattle Markets, Western Journal of Agricultural Economics, Vol. 14, Hal. 246-252

Capps, Jr., Oral dan Pablo Sherwell (2005), Spatial Asymmetry in FarmRetail Price Transmission Associated with Fluid Milk Product, Department of Agriculture Texas A\&M University 
Gujarati, Damodar N. (2005), Basic Econometrics 4th ed., Singapore: McGraw-Hill

Komisi Pengawas persaingan Usaha (2007), Laporan Evaluasi dan Kajian Dampak Kebijakan Persaingan Terkait Dengan Industri Minyak Goreng Sawit

Manera, Matteo dan Grasso, Margherita (2005), Asymmetric Error Correction Models for the Oil-Gasoline Price Relationship, FEEM Working Paper No. 75.05. Dapat diperoleh di SSRN: http:/ / ssrn.com/abstract $=731524$

Meyer, Jochen dan Stephan von Cramon-Taubadel (2004), Asymmetric Price Transmission: A Survey, Journal of Agricultural Economics Vol. 55 Tahun 2004, Halaman 581 - 611

Shepherd, William, G. (1990), The Economics of Industrial Organization, 3rd edition, Prentice-Hall, Inc

Vavra, P dan B.K. Goodwin (2005), Analysis of Price Transmission Along the Food Chain, OECD Food, Agriculture and Fisheries Working Papers, No. 3, OECD Publishing

Ward, RW (1982), Asymmetry in Retail, Wholesale, and Shipping Point Pricing for Fresh Vegetables, American Journal of Agricultural Economics, Vol. 62, hal. 205-212 